УДК $811.161 .2^{\prime} 373.7$

І. М. Клименко

\title{
СЕМАНТИЧНИЙ АСПЕКТ ЗІСТАВЛЕННЯ АНГЛІЙСЬКИХ ТА УКРАЇНСЬКИХ ФРАЗЕОЛОГІЧНИХ ОДИНИЦЬ
}

Клименко I. М. Семантичний аспект зіставлення англійських та українських фразеологічних одиниць.

У статті досліджується семантичний аспект зіставлення англійських та українських фразеологізмів, розглядається проблема визначення типів міжмовних відношень на

(C) І. М. Клименко, 2013. 
лексико-семантичному рівні. Аналізуються випадки еквівалентності, включення, пересічення та безеквівалентності на прикладі фразеологічних систем зазначених мов.

Ключові слова: міжмовні відношення, фразеологічна система, еквівалентність, включення, пересічення, безеквівалентність.

Клименко И. М. Семантический аспект сопоставления английских и украинских фразеологических единиц.

В статье исследуется семантический аспект сопоставления английских и украинских фразеологизмов, рассматривается проблема определения типов межъязыковых отношений на лексико-семантическом уровне. Анализируются случаи эквивалентности, включения, пересечения и безэквивалентности на примере фразеологических систем указанных языков.

Ключевые слова: межъязыковые отношения, фразеологическая система, эквивалентность, включение, пересечение, безэквивалентность.

Klymenko I. M. The semantic aspect of comparing English and Ukrainian phraseological units.

The paper examines the semantic aspect of comparing English and Ukrainian set expressions, the problem of interlingual relations at the lexical level. It studies the cases of equivalence, inclusion, overlapping and non-equivalence in the systems of English and Ukrainian phraseology.

Key words: interlingual relations, phraseological system, equivalence, inclusion, overlapping, non-equivalence.

Усю багатогранність відношень лексичних одиниць, що зіставляються в мовах, зводять здебільшого до трьох основних типів: повний збіг (еквівалентність); частковий збіг (з двома різновидами - включенням та пересіченням семантики); незбіг (виключення). Розглянемо кожен з цих типів детальніше стосовно фразеологічних одиниць англійської та української мов.

Лексико-семантичні відношення збігу: еквівалентність. Лексичний рівень мови має своєю одиницею дослідження не тільки слово, але й стійке сполучення слів, або фразеологічну одиницю. Більшість теорій, що описували типи міжмовних лексико-семантичних відношень, стосувалися лише слів [1;5;8].

3 поняттям еквівалентності зіштовхується кожен лінгвіст, що вивчає різні типи порівнянь - мовні та позамовні. Категорію еквівалентності в певному сенсі можна вважати центральною й універсальною при дослідженні різних відношень мовних одиниць на системному рівні, бо основна мета аналізу мов - це встановлення складу i функцій за інтегральними (еквівалентними) і диференційними ознаками [6, с. 124].

Еквівалентність розуміють як рівноцінність, рівнозначність. Виходячи з цього, еквівалентними необхідно вважати такі одиниці А і В, які повністю збігаються за всіма ознаками в рамках однієї або різних систем, що зіставляються, тобто одиниці між якими встановлюються відношення тотожності: $\mathbf{A}=\mathbf{B}$. Часто такий тип відношення лексичних одиниць визначають як базовий, відправний, як такий, стосовно якого розглядають інші лексико-семантичні відношення. Так, вважають, наприклад, що взаємоеквівалентними є фразеологічні одиниці на зразок: to wash one's hands - «умити руки»; in the twinkling of an eye - «миттю ока»; a millstone about smb. 's neck (C) І. М. Клименко, 2013. 
«камінь на шиї»; not to let one's left hand know what one's right hand does «ліва рука не відає, що робить права»; from the bottom of one's heart - «від усього серця»; to cherish a viper $i$ one's bosom - «пригріти змію на грудях».

У проілюстрованих прикладах еквівалентність виявляється у збігові як смислу, так і структури й образного ряду. На фразеологічному рівні при зіставленні англійської та української мови не доводиться говорити про значну кількість взаємоеквівалентих одиниць, але фразеологізми все ж більш репрезентативні, ніж просто слова.

Якщо виходити 3 необхідності суміщення ономасіологічного та семасіологічного аспектів при аналізі лексико-семантичних відповідностей у мовах, що зіставляються, то кількість взаємоеквівалентних одиниць-слів невелика навіть у споріднених мовах. Але таке суміщення $є$ важливим переважно на загальнотеоретичному рівні для засвідчення різного уявлення конкретними національно-мовними культурами єдиного когнітивносемантичного простору. Категорію еквівалентності варто застосовувати тільки до таких лексико-семантичних відповідностей, які мають максимальний збіг у складі і змісті семантичних ознак, що входять у структуру їх лексичних значень. Про встановлення еквівалентності на рівні змістовної структури говорити складно, бо словникові дефініції структурують найбільш імовірні моделі лексичних значень, а не змістів лексичних одиниць, лексичне значення $\epsilon$ найбільш стійкою сутністю, що найближче розташоване до концептів мислення та реальності [3, с. 115]. Змістовна структура лексичної одиниці, зокрема її імплікаційна частина, кожному, хто займається контрастивним аналізом лексики різних мов, допомагає визначити реальну семантичну спорідненість або неспорідненість тієї чи тієї пари. Необхідність безпосереднього використання змістовної структури лексичної одиниці при зіставленні лексико-семантичних відповідностей виникає лише тоді, коли словниковий варіант структури значення викликає сумніви, потребує уточнення.

Відношення часткового збігу, або включення, означає, що у значенні лексичної одиниці наявна більша кількість сем, ніж у значенні відповідної одиниці іншої мови, тобто в семний склад значення лексичної одиниці А входить усе значення одиниці мови В плюс ще якісь семи чи навпаки. Стосовно фразеології відношення включення можна сформулювати як наявність у лексикосемантичній структурі фразеологічної одиниці більшої (меншої) кількості варіантів значень, ніж у структурі фразеологізму іншої мови [5, с. 339-340].

На рівні слова міжмовні лексико-семантичні відношення виявляються ширше, ніж у фразеології. Вони, наприклад, відбиваються у гіпо-гіперонімічних відмінностях. Гіперонімія - це недиференційованість значень однієї мови щодо іншої, де ці значення диференціюються (гіпонімія). Такі відношення трапляються в різних мовах і стосуються широких тематичних пластів лексики. Так, англійському слову coat в українській мові відповідають різні види верхнього одягу: пальто, плащ, мундир, китель. Гіпо-гіперонімічні відношення на фразеологічному підрівні не спостерігаються, але інші 
аспекти відношення включення, що охоплюють семантичну структуру фразеологізму, наявні. В англійській та українській мовах $є$ одиниці 3 різною кількістю лексико-семантичних варіантів значення. Наприклад, порівняйте: to be born with a silver spoon in one's mouth - 1. «to be born under a lucky star, to be lucky»; 2. «to be born into a wealthy family» та народитися у сорочці - «бути щасливим, таланистим»; on smb's hands «resting on one as a responsibility» та на руках - 1. «під опікою»; 2. «у розпорядженні, у володінні»; behind smb's back - «without his knowledge (always in connection with smth unpleasant, such as slender)» та поза очі1. «у відсутність, щоб ніхто не чув і не бачив»; 2. «не бачачи особисто».

Відношення включення, на думку семасіологів, є важливим показником у зіставній семасіології. Вони демонструють, що в одній мові той чи той предмет не має спеціального найменування, тобто певне поняття, яке існує в мисленні носіїв мови у вигляді комплексу семантичних ознак, не закріплене окремим словесним знаком, і для висловлення відповідного поняття використовують найменування більшого класу предметів, у той час як в іншій мові певне явище виокремлюється семою. Ця ознака більшою мірою характерна для неспоріднених мов.

Відношення включення сприяють виявленню особливостей лексичних одиниць, що порівнюються, у семантико-стилістичному та конотативнопрагматичному планах. Тут можна спостерігати значні для національних культур особливості диференціації концептів. Слід зазначити, що врахування відношень включення між значеннями одиниць, що зіставляються, $\epsilon$ суттєвим у художньому перекладі.

Відношення часткового збігу, або пересічення, $(\mathbf{A} \cap \mathbf{B})$ спостерігаються тоді, коли значення нібито накладається одне на інше, але в кожного 3 них залишається й розрізнювальна складова. Для відношення пересічення застосовується також термін гетеронімія. Цей тип відношення об'єднує такі пари лексико-семантичних відповідностей мов, що зіставляються, які означають дещо різні, але дуже схожі за своєю природою і функціям денотати й уявлення про них. Наприклад, to be on one's feet - 1. «be standing»; 2. «rise (to speak)»; 3. «be in good health after an illness» та бути на ногах - 1. «не спати»; 2. «клопотати, перебувати у турботах»; 3. «бути здоровим після хвороби»; 4. «стояти».

У наведених прикладах значення, що не перетинаються, - це «rise (to speak)» in «to be on one's feet» та «не cnamu» у «бути на ногах». Крім того, значення «стояти» має різну частотність в англійській та українській мовах. В українській воно вживається рідко. Останні лексико-семантичні варіанти утворюють компонент пересічення.

Інші приклади фразеологізмів із відношеннями пересічення в англійській та українській мовах: to throw dust in one's eyes - «to mislead someone, to prevent from seeing the truth» та замилювати очі-«за допомогою ефектних учинків представляти свій стан кращим, ніж він є»; Jack of all

(C) І. М. Клименко, 2013. 
trades - «person who can turn his hand to anything, workman knowing something of many trades (a master of none)» та майстер на всі руки «людина, здатна до будь-якої справи, що вміє все робити майстерно». В останньому прикладі компонент, що не збігається - це конотація. В англійській мові вона негативна, в українській - позитивна. Лексикосемантичні відношення пересічення спостерігаються також у фразеологічних одиницях $з$ однаковим значенням та з різним образним компонентом, з різною метафоричною базою, що визначається особливостями національного сприйняття дійсності. До таких фразеологізмів належать: a bird in hand is worth two in the bush - краще синиця в руиі, ніж журавель у небi; to sleep with one еуе ореп - одним вухом спить, іншим чує.

Окрему групу становлять фразеологізми, у яких в англійській та українській мовах збігаються змістові компоненти, але в одній з мов відсутній образний метафоричний компонент. Наприклад: of the right kidney - вidnовidний, цілком порядний; to stick to smb's rib - бути ситним, тривним; to get one's brains fried - отримати сонячний удар; to pass опе's lips - проковтнути, з '̈сти, випити; to put a bold face on smth - діяти сміло, не розгубитися.

Лексико-семантичними відношеннями часткового збігу в англійській та українській мовах пов'язані фразеологізми з різним значенням, але спільною структурою та ії компонентами. Такі одиниці часто називають хибними друзями перекладача. До них належать: англ. to lead by the nose «помикати», укр. водити за носа - «дурити»; англ. to stretch one's legs «порозминати ноги, прогулятися», укр. протягнути ноги - «вмертии»; англ. to twist smb round one's finger - «заставити діяти за чиїмось бажанням, позбавивши власної волі», укр. обвести навколо пальия - «обдурити».

Слід зауважити, що пересічення фразеологічних значень $є$ досить поширеним явищем при міжмовних порівняннях, і з позиції контрастивного аналізу являє собою цікавий матеріал. Відношення часткового збігу можуть стосуватися конотативно-прагматичного рівня. I не завжди зіставляється семантичний компонент. Відмінності можуть стосуватися стилістичних особливостей, сфери мовних концептуальних понять, так званої етнічної ментальності взагалі.

Подібно до того, як різні мови знаходяться одна до одної у відношенні тотожності відмінностей, так і окремі лексико-семантичні відповідності взаємоеквівалентними є тільки умовно й у якомусь одному лінгвістичному вимірі [6, с. 138]. Ступінь еквівалентності двох зіставлюваних лексичних одиниць, що в принципі збігаються у значеннях, визначається ступенем їх змістових відмінностей: найбільш еквівалентними $€$ такі значення одиниць, що порівнюються, які мають мінімальні відмінності у своїх змістових структурах. Крайніми кордонами, що визначають семантичну відстань між лексичними одиницями, є відношення повного збігу (еквівалентності) i повного незбігу (безеквівалентності). Останній тип відношень стане об’єктом розглянення в наступному підрозділі. 
Відношення незбігу, або безеквівалентність, ілюструються фразеологізми, семантика яких співвідноситься 3 позначенням специфічних для певної культури реалій. Реалії є унікальними одиницями, що певною мірою нема з чим порівнювати. Про безеквівалентну лексику, для якої використовують терміни «етнографізми», «фонові слова», «одиниці 3 культурним компонентом» тощо, чимало сказано дослідниками в галузі лінгвокраїнознавства та перекладу [2;7]. Безеквівалентними є одиниці, змістовий план яких неможливо зіставити 3 якимось іншомовним лексичним поняттям. Царина дослідження подібних одиниць відкриває багаті аспекти національних культур, виявити невивчені етнічні факти.

Можна виділити різні рубрики найменувань (тематичні групи), що належать до позначення предметів матеріальної і духовної культури національних соціумів. Наведемо приклади деяких з них, у яких представлені фразеологізми 3 соматичним компонентом: blue nose - «синій ніс», прізвисько жителів Канади та північно-східних штатів США, особливо штату Мен; rabbit's foot - кроляча лапка, що має магічну силу; buck eye кінський каштан, що використовується як талісман. Два останні приклади фразеологічних одиниць пов'язані $з$ марновірством, забобонами, які $\epsilon$ частиною культури англомовних країн.

Безеквівалентні сталі сполучення також представлені прізвиськами підлітків, узятих із коміксів, мульфільмів, у яких є своя логіка, грунтована на взаємовідносинах персонажів джерела запозичення [2, с. 68]. Наприклад: Big mouth («великий рот», «базіка»); Bird brain («курячий мозок»); Numb skull («пустий череп»); Horse face («коняча пика»). В українській мові явище надання прізвиськ з використанням соматичних компонентів серед підлітків теж досить поширене.

У зв'язку з безеквівалентними фразеологізмами виникає питання про способи їх передачі в іншій мові. Найбільш поширені з них - це калькування (blue nose - «синій ніс») та описовий переклад. Іноді для більш повного тлумачення ці обидва способи комбінуються.

\section{Література}

1. Верба Л. Г. Порівняльна лексикологія англійської та української мов / Л. Г. Верба. - Вінниця : Нова книга, 2003. -160 с.

2. Влахов С. И. Непереводимое в переводе / С. И. Влахов, С. П. Флорин. - М. : Р. Валент, 2006. -448 с.

3. Гак В. Г. Сопоставительная лексикология / В. Г. Гак. - М. : Международные отношения, 1977. $-246 \mathrm{c}$.

4. Гак В. Г. Языковые преобразования / В. Г. Гак. - М. : Наука, 1998. - 312 с.

5. Кочерган М. П. Основи зіставного мовознавства / М. П. Кочерган. - К. : Академія, 2006.- 424 с.

6. Манакин В. Н. Сравнительная лексикологія / В. Н. Манакин. - К. : Знання, 2004. - 326 с.

7. Швейцер А. Д. Перевод и лингвистика / А. Д. Швейцер. - М. : Наука, 1973. - 325 с.

8. Korunets I. V. Contrastive Typology of the English and Ukrainian Languages / I. V. Korunets. - K. : Lybid, 1995. - 239 p.

(ㄱ.М.Клименко, 2013. 